\title{
Assessment of HFE mutations in patients with iron overload
}

Gastroenterology and Hepatology Unit, Portuguese Hospital of Salvador,

Salvador, Bahia, Brazil.

I read with interest the recently published manuscript from Cançado et al. ${ }^{1}$ concerning HFE genotyping of 35 Brazilian patients with iron overload. The authors had found five subjects homozygous for the $\mathrm{C} 282 \mathrm{Y}$ mutation, four that had compound heterozygosity for $\mathrm{C} 282 \mathrm{Y} / \mathrm{H} 63 \mathrm{D}$ and 17 subjects with at least one of the aforementioned HFE gene mutations. Sixteen of the patients had secondary causes of hemochromatosis ${ }^{2,3}$ due to hemolytic anemia, hepatitis $\mathrm{C}$ and alcoholic liver disease.

Based on these results, the authors described the presence of hereditary hemochromatosis in 10 patients (28\%). They also reported a high frequency of $\mathrm{C} 282 \mathrm{Y} / \mathrm{H} 63 \mathrm{D}$ heterozygotes $(44 \%)$ in subjects with secondary iron overload, thus suggesting a role for HFE mutations in the development of iron overload in subjects with secondary hemochromatosis.

These findings should be interpreted with caution and some questions have to be raised in order to understand the role of HFE genotyping in patients with iron overload.

First, it is important to highlight that the authors have not defined any criteria for iron overload. Some of their patients had normal transferrin saturation and all had increased ferritin concentration. In addition, no information regarding liver biopsy was provided and it remains unknown whether those patients with hepatitis $\mathrm{C}$ or alcoholic liver disease would have been found to have siderosis on liver biopsy. It also has to be acknowledged that, to date, most patients with nonalcoholic steatohepatitis, hepatitis $\mathrm{C}$ and alcoholic liver disease who presented elevated transferrin saturation and ferritin levels have not had siderosis on liver biopsy. ${ }^{2-4}$

It was further reported that $10(28 \%)$ of the patients in the study had hereditary hemochromatosis, on the basis of HFE typing. This assumption may be misleading, since the absence of HFE mutations does not rule out hereditary hemochromatosis. ${ }^{2,3}$ Indeed, approximately $40 \%$ of Brazilian patients with a well-defined phenotype of hereditary hemochromatosis lack classical HFE mutations, thus suggesting the occurrence of other HFE and non-HFE mutations in Brazilian subjects with hereditary hemochromatosis. ${ }^{5}$

Conversely, it was assumed that 10 patients in the study had hereditary hemochromatosis, on the basis of the presence of several different HFE genotypes. This could also be misleading, since liver biopsy is still necessary for diagnosing hereditary hemochromatosis in subjects who are not homozygous for the $\mathrm{C} 282 \mathrm{Y}$ mutation, ${ }^{3}$ because of the frequency of these genotypes in the general population., ${ }^{2,3}$

Therefore, it has to be stressed that clear-cut criteria must be used to describe the phenotypes of hereditary hemochromatosis and secondary hemochromatosis. Patients with secondary hemochromatosis do not need to be HFE typed. On the other hand, HFE typing should be performed on subjects with primary iron overload characterized by elevated transferrin saturation and ferritin levels. In those iron-loaded subjects, homozygosity for the $\mathrm{C} 282 \mathrm{Y}$ mutation leads to a diagnosis of hereditary hemochromatosis. Any other HFE genotype would require liver biopsy to assess the presence of siderosis. In geographical areas or in families where roles for other ironloading genes have been revealed, mutations in other HFE and non-HFE genes could be contributory factors for a diagnosis of hereditary hemochromatosis. ${ }^{3}$

\section{AUTHQR INFORMATION}

Paulo Lisboa Bittencourt, MD, PhD. Coordinator of the Gastroenterology and Hepato ogy Unit, Portuguese Hospital of Salvador, Salvador, Bahia, Brazil.

\section{Address for correspondence:}

Paulo Lisboa Bittencourt

Rua Clementino Fraga, 220 - Apto. 1901, Ondina

Salvador (BA) - Brasil - CEP 40170-050

Tel. (+55 71$)$ 203-3457 - Fax. (+55 71) 203-3456

E-mail: plbbr@uol.com.br

Copyright @ 2007, Associação Paulista de Medicina
1. Cançado RD, Guglielmi AC, Vergueiro CS, Rolim EG, Figueiredo MS, Chiattone CS. Analysis of HFE gene mutations and HLA-A alleles in Brazilian patients with iron overload. Sao Paulo Med J. 2006;124(2):55-60.

2. Siah CW, Ombiga J, Adams LA, Trinder D, Olynyk JK. Normal iron metabolism and the pathophysiology of iron overload disorders. Clin Biochem Rev. 2006;27(1):5-16.

3. Tavill AS; American Association for the Study of Liver Diseases; American College of Gastroenterology; American Gastroenterological Association. Diagnosis and management of hemochromatosis. Hepatology. 2001;33(5):1321-8.

4. Deguti MM, Sipahi AM, Gayotto LC, et al. Lack of evidence for the pathogenic role of iron and HFE gene mutations in Brazilian patients with nonalcoholic steatohepatitis. Braz J Med Biol Res. 2003;36(6):739-45.
5. Bittencourt PL, Palacios SA, Couto CA, et al. Analysis of HLA-A antigens and C282Y and $\mathrm{H} 63 \mathrm{D}$ mutations of the HFE gene in Brazilian patients with hemochromatosis. Braz J Med Biol Res. 2002;35(3):329-35.

Sources of funding: Not declared

Conflict of interest: Not declared

Date of first submission: August 22, 2006

Last received: September 6, 2006

Accepted: December 28, 2006 


\section{RESPRNSE}

In 2002, an expert panel gathered to consider a new definition for hereditary hemochromatosis and at that time it was emphasized that "the disease of hereditary hemochromatosis is defined in terms of phenotype not genotype. Thus, the identification of any of the HFE mutations is, by itself, insufficient for the diagnosis of this disease. Instead, the identification of the genetic abnormality provides evidence of susceptibility to developing the phenotype". ${ }^{1}$ In this regard Beutler wrote: "the HFE Cys282Tyr mutation is a necessary but not sufficient cause of clinical hereditary hemochromatosis". ${ }^{2}$

Most cases (averaging 85\%-90\%) of hereditary hemochromatosis are caused by homozygosity for the C282Y mutation in the HFE gene. Another 3\%-5\% of patients with this disease are compound heterozygotes (C282YH63D). ${ }^{3}$

Patients with iron overload, particularly if they have environmental or other causes of iron accumulation and tissue injury (such as iron-loading anemia, chronic hemolysis, blood transfusions, excess dietary intake, hepatitis C, alcoholism, or steatohepatitis), should be considered to have acquired iron overload even if they are heterozygous for $\mathrm{C} 282 \mathrm{Y}$ or $\mathrm{H} 63 \mathrm{D}$ (found in $10 \%-20 \%$ and $15 \%-30 \%$ of persons of Northern European extraction, respectively). ${ }^{3}$
In our study, the criteria for diagnosing iron overload included two fasting measurements of the transferrin saturation index (TS), with results $\geq 60 \%$ in males and $\geq 50 \%$ in females, and/or serum ferritin concentrations exceeding $300 \mathrm{ng} / \mathrm{ml}$ in males or $200 \mathrm{ng} / \mathrm{ml}$ in females.

According to Powell (2002), the criteria for diagnosing established hereditary hemochromatosis include at least one of the following in the absence of other known causes of iron overload: 1) Stainable hepatic iron grade 3 or 4; 2) Hepatic iron concentration $>80 \mathrm{mM} / \mathrm{g}$ (dry weight); 3) Hepatic iron index (hepatic iron concentration/age) > 1.9; 4) Removal of $5 \mathrm{~g}$ of iron or more by therapeutic phlebotomy without inducing iron deficiency; 5) Diagnosis of HFE-associated hemochromatosis, confirmed by demonstration of homozygosity for the C2828Y mutation or compound heterozygosity for C282Y and H63D. ${ }^{4}$

In our study, 12 out of 35 iron overload patients underwent liver biopsy. All of them presented hepatic siderosis (grade 3 or 4 stainable hepatic iron). Their main clinical and laboratory characteristics are shown in Table 1.

In some patients with secondary hemochromatosis, it is important to study the HFE mutations, especially in those who present iron overload much greater than expected.
Heterozygosity for C282Y or H63D may contribute towards iron overload because of another condition, but should not be considered to be the only cause of iron overload or as diagnostic for hereditary hemochromatosis.

Bacon et al. observed that in many chronic liver diseases, heterozygosity of mutations in HFE may contribute to iron overload. ${ }^{3}$ We observed that the beta-thalassemia trait might increase the severity of hemochromatosis in subjects with the $\mathrm{C} 282 \mathrm{Y}$ mutation in the HFE gene. ${ }^{5}$ Piperno et al. demonstrated that the beta-thalassemia trait aggravated the clinical condition of $\mathrm{C} 282 \mathrm{Y}$ homozygotes, thus favoring higher rates of iron accumulation and the development of severe iron-related complications. They suggested that the coexistence of the beta-thalassemia trait might also increase the risk of iron overload in patients with HFE genotypes who were at mild risk of hemochromatosis. ${ }^{6}$

We agree with Bittencourt PL that the absence of HFE mutations does not rule out hereditary hemochromatosis. We know that there are other hereditary forms of this disease that may be secondary to other mutations in the HFE gene or other genes involved in iron metabolism. We are now studying a mutation in the transferrin receptor- 2 gene and in the DMT-1 gene, among patients with iron overload and normal HFE genotype.

Table 1. Main clinical and laboratory characteristics of 12 Brazilian patients with grade 3 or 4 hepatic siderosis from liver biopsy

\begin{tabular}{|c|c|c|c|c|c|c|c|c|}
\hline $\begin{array}{l}\text { Age } \\
\text { (years) }\end{array}$ & Gender & Genotype & $\begin{array}{l}\text { Transferrin saturation } \\
\text { index }(\%)\end{array}$ & $\begin{array}{c}\text { Serum ferritin } \\
\mathrm{ng} / \mathrm{ml}\end{array}$ & Hepatitis C & $\begin{array}{l}\text { Hepatic } \\
\text { cirrhosis }\end{array}$ & $\begin{array}{l}\text { Excessive alcohol } \\
\text { consumption }\end{array}$ & $\begin{array}{l}\text { Chronic hemolytic } \\
\text { anemia }\end{array}$ \\
\hline 57 & M & C282Y/C282Y & 66.0 & 4218.0 & No* & No & No & No \\
\hline 55 & M & $\mathrm{C} 282 Y / C 282 Y$ & 77.0 & 2200.0 & No* & No & No & No \\
\hline 59 & $\mathrm{~F}$ & C282Y/C282Y & 83.0 & 1265.0 & No† & Yes & No & No \\
\hline 54 & $\mathrm{~F}$ & $\mathrm{C} 282 \mathrm{Y} / \mathrm{C} 282 \mathrm{Y}$ & 75.0 & 1883.0 & No* & No & No & Yes* \\
\hline 67 & $\mathrm{~F}$ & $\mathrm{C} 282 \mathrm{Y} / \mathrm{C} 282 \mathrm{Y}$ & 85.0 & 5265.0 & Not & Yes & No & No \\
\hline 54 & $\mathrm{~F}$ & $\mathrm{C} 282 \mathrm{Y} / \mathrm{H} 63 \mathrm{D}$ & 66.0 & 2324.0 & Not & Yes & No & No \\
\hline 67 & M & $\mathrm{C} 282 \mathrm{Y} / \mathrm{H} 63 \mathrm{D}$ & 57.0 & 1359.0 & No* & No & No & Yes* \\
\hline 47 & $\mathrm{~F}$ & C282Y/WT & 67.0 & 324.0 & Yes* & No & No & No \\
\hline 54 & M & C282Y/WT & 68.0 & 1200.0 & No* & No & No & No \\
\hline 42 & $F$ & H63D/WT & 57.0 & 2500.0 & No* & No & No & Yes $\dagger$ \\
\hline 44 & M & H63D/WT & 55.0 & 1573.0 & Yes* & No & No & No \\
\hline 51 & M & WTWT & 65.0 & 1180.0 & Yes* & No & Yes & No \\
\hline
\end{tabular}

$M=$ male; $F=$ female; $W T$ (wild type) $=$ Normal; ${ }^{*}=$ hereditary spherocytosis; $\dagger=$ alpha thalassemia 


\section{AUTHOR INFORMATION}

Rodolfo Delfini Cançado, MD, PhD. Assistant professor of Hematology, Discipline of Hematology and Oncology, Department of Internal Medicine, Faculdade de Ciências Médicas da Santa Casa de Misericórdia de São Paulo, São Paulo, Brazil.

\section{Address for correspondence:}

Rodolfo Delfini Cançado

Hemocentro da Santa Casa de São Paulo

R. Marquês de ltu, 579 - 3o andar

São Paulo (SP) - Brasil - CEP 01223-001

E-mail: rdcan@uol.com.br

Copyright $\odot$ 2007, Associação Paulista de Medicina

\section{REFERENCES}

1. McCullen MA, Crawford DH, Hickman PE. Screening for hemochromatosis. Clin Chim Acta. 2002;315(1-2): $169-86$.

2. Beutler E. The HFE Cys282Tyr mutation as a necessary but not sufficient cause of clinical hereditary hemochromatosis. Blood. 2003;101(9):3347-50.

3. Bacon BR, Powell LW, Adams PC, Kresina TF, Hoofnagle JH. Molecular medicine and hemochromatosis: at the crossroads. Gastroenterology. 1999;116(1):193-207.
4. Powell LW. Hereditary hemochromatosis and iron overload diseases. J Gastroenterol Hepatol. 2002;17 Suppl:S191-5. 5. Arruda VR, Agostinho MF, Cançado R, Costa FF, Saad ST. Beta-thalassemia trait might increase the severity of hemochromatosis in subjects with the $\mathrm{C} 282 \mathrm{Y}$ mutation in the HFE gene. Am J Hematol. 2000;63(4):230.

6. Piperno A, Mariani R, Arosio C, et al. Haemochromatosis in patients with beta-thalassaemia trait. $\mathrm{Br} \mathrm{J}$ Haematol. 2000;111(3):908-14.

Sao Paulo Med J. 2007; 1 25(1):65-7 